\title{
STATISTICAL ANXIETY AND METACOGNITIVE AWARENESS LEVELS OF GRADUATE STUDENTS STUDYING IN MATHEMATICS EDUCATION PROGRAM
}

\author{
Murat Altun ${ }^{1}$, \\ Gül Kaleli Yılmaz², \\ Barış Demiriri, \\ Hülya Sert Çelik ${ }^{4}$ \\ 1Prof. Dr., \\ Faculty of Education, \\ Bursa Uludağ University, \\ Bursa, Turkey \\ ${ }^{2}$ Assoc. Prof., \\ Faculty of Education, \\ Bursa Uludağ University, \\ Bursa, Turkey \\ ${ }^{3} \mathrm{PhD}$ Student, \\ Faculty of Education, \\ Bursa Uludağ University, \\ Bursa, Turkey \\ ${ }_{4}^{4} \mathrm{PhD}$ Student, \\ Faculty of Education, \\ Bursa Uludağ University, \\ Bursa, Turkey
}

\begin{abstract}
:
Graduate students are faced with some difficulties in determining statistical methods to be used in their assignments and researches and this leads to anxiety in them. In this study, it was aimed to examine the relationships between statistical anxiety and metacognitive awareness levels of graduate students studying in the field of mathematics education and to compare these levels in terms of some variables. The research study group consists of 101 students studying at the master's and doctorate levels in the department of mathematics education and participated in the research voluntarily. As a data collection tool in the research, Statistical Anxiety Scale (SAS) and Metacognitive Awareness Scale (MCAS) were used. In the analysis of the data, descriptive statistics, $t$ test, ANOVA and Correlation Coefficient were used. According to the research results, it was determined that there is a negative and moderately significant relationship between statistical anxiety and metacognitive awareness levels of graduate students studying in the field of mathematics education. As a result of the analyzes, it was observed that the
\end{abstract}

'Correspondence: email baris.demir@kocaeli.edu.tr 
statistical anxiety and metacognitive awareness of the students were high, the statistical anxiety and metacognitive awareness levels differed statistically according to the variables of graduate education level and stage of graduate education, but did not differ significantly according to the variables of gender and taking statistics course.

Keywords: graduate education, mathematics education, metacognitive awareness, statistics anxiety

\section{Introduction}

Mathematics is largely the product of the curiosity to know and understand the truth, and some mathematics arose from practical needs. It facilitates life in terms of mathematical results or helps produce thoughts that will make it easier. The value of statistics can also be evaluated in this context as a branch of mathematics (Altun, 2018). In an environment of uncertainty, statistics is seen as a science that uses research, decision-making and estimation mechanisms together and develops them and a technology of other disciplines (Koparan and Güven, 2014). The literature emphasizes the importance and role of statistics in daily life (Guidelines Assessment in Statistic Education [GAISE], 2005, 2006; Ben-Zvi \& Garfield, 2008; Schield, 2008). In the GAISE (2005) report, which is one of them; it is underlined that our life is surrounded by qualitative and quantitative contexts, and a high school graduate should be equipped with sufficient statistical knowledge and skills to cope with the situations in his/her life and to have a productive and peaceful life. It is also important for a researcher who will conduct research in the relevant field to follow the literature, analyze his/her data and understand the studies conducted (Tan, 2016). For these reasons, statistics is seen as a tool that complements scientific research (Sutarso, 1992). In addition, researchers who conduct scientific studies are expected to know statistical techniques and research methods (Erkuş, 2011). As it is known, the level of education in which scientific studies gain importance is graduate education. One of the ultimate goals of graduate education is to train and gain scientists who have analytical thinking skills, who are creative, sensitive to ethical principles, who produce solutions, who have an academic perspective, who willingly participate in group work and interdisciplinary studies, who produce quality studies and who can meet the needs of society (Aslan, 2016). In this context, having statistical knowledge plays a vital role in graduate education.

A statistics course is a must to take in almost all of the graduate education programs in social sciences, behavioral sciences and educational sciences, where it is valuable to have statistical knowledge. However, statistics course is a negative experience for most graduate students (Collins \& Onwuegbuzie, 2007). Anxiety about any lesson negatively affects the achievement of the desired goals of the lesson besides causing the lesson to be perceived as more difficult than it is. In other words, anxiety is a negative condition that affects academic performance (Sutarso, 1992; Onwuegbuzie \& Wilson, 2003). In addition, anxiety is a condition that manifests itself with physiological 
symptoms, which negatively affect academic achievement. Lei (2008) stated that high anxiety levels reduce people's sense of self-efficacy and develop a negative attitude towards scientific research. This situation may cause many students to be afraid of taking statistics courses and delay taking these courses until the end of an undergraduate program (Roberts \& Bilderbeck, 1980), not be able to graduate from the program they are enrolled in (Onwuegbuzie, 1997), and may affect their success in research methods courses (Onwuegbuzie, Slate, Paterson, Watson, and Schwartz, 2000). This and similar student behaviors are explained with statistics anxiety. It is stated that approximately $80 \%$ of graduate students experience this situation (Onwuegbuzie \& Wilson, 2003). According Onwuegbuzie et al., (1997), statistics anxiety refers to the anxiety that arises when individuals are confronted with statistics (data collection, analysis and interpretation) in any way and at any level. Because statistics anxiety is situation-specific, symptoms occur only in a particular situation and time-while learning or applying statistics in a formal setting (Onwuegbuzie et al., 1997; Zeidner, 1991). Many students tend to experience high levels of statistical anxiety when faced with statistical ideas, problems or problems, instructional situations, or evaluative situations (Onwuegbuzie \& Seaman, 1995; Zeidner, 1991).

Besides anxiety, it is thought that metacognition is an important factor in students' learning of statistics. The concept of "metacognition" is an important concept that gained fame in education in the 1970s. According to Flavell (1979), one of the founders of metacognition, metacognition refers to the individual's knowledge of cognitive processing and output or similar things related to the situation. Cognition is about being aware of a situation and understanding it, but metacognition is about knowing how a situation is understood or how it is learned (Senemoğlu, 2015). According to Schneider and Artelt (2010, p. 149), metacognition includes people's own information processing skills and their ability to monitor and self-regulate their cognitive activities. In many studies dealing with metacognition, it is emphasized that metacognition has an important place in the education of students and increasing their success (Balc1, 2007; Copper, 2008; Georghiades, 2004; Landine \& Stewart, 1998; Tuncer, 2011). In the study conducted by Schneider and Artelt (2010), theoretical and experimental studies on metacognition in mathematics education in recent years were examined, and attention was drawn to the importance of metacognition.

When the literature is examined, it is seen that many studies have been conducted on statistics anxiety (Baloğlu, 2003; Baloğlu \& Zelhart, 2004; Beurze et al., 2013; Onwuegbuzie, 2004; Primi \& Chiesi, 2018; Roberts \& Saxe, 1982; Wilson, 1997). At the same time, studies on the anxiety levels of undergraduate and graduate students towards scientific research were also found (Aslan and Karagül, 2016; Bayar et al., 2013; Büyüköztürk, 1997; Saracaloglu et al., 2005; Saracaloglu, 2008; Tekin, 2007; Y1lmaz and Çokluk, 2010). In addition, many studies have been conducted on metacognitive awareness (Bağçeci et al., 2011; Çikrıkci and Odacı, 2013). There are even studies examining the relationships between anxiety and metacognitive awareness (Gökbulut and Akdağ, 2016; Öztürk and Serin, 2020; Spada et al., 2010). These studies concluded 
that there is a significant relationship between metacognitive awareness and anxiety in general.

\subsection{Objective and Importance of the Study}

The inclusion of statistical information in every field in daily life attracted the attention of program developers, and then reform movements began in curricula (NCTM, 2000). For this reason, the achievements in the field of statistics have an important place in mathematics teaching programs. In addition, the achievements in the secondary school mathematics curriculum are discussed at each grade level and in more detail. Along with the mentioned reform movements, it is expected that statistics education is of great importance and that the teachers who perform this education should have some skills and field knowledge. In terms of teaching mathematics, metacognition skills have an important place in increasing the success of their students for teachers. For this reason, it is important for students to notice, model and internalize the expressions and behaviors of teachers towards their metacognitive awareness (Schunk, 1989). Therefore, it can be said that teachers' metacognitive awareness levels are very effective in improving students' metacognitive skills. It is expected that the person will have less anxiety about the situations when metacognitive awareness is characterized as a system that controls the information one has. It is expected that an individual who knows to what extent his/her knowledge and skills are, and which method s/he will use to apply it, and most importantly, is aware of his/her weaknesses, will be less anxious than an individual who does not have this awareness. For this reason, although anxiety is a negative attitude, it is thought that the factors affecting it may also directly affect anxiety. For this reason, it is desirable that teachers' metacognitive awareness is high and their anxiety levels are low during the teaching processes in statistics courses. Because the first goal of statistics education should be to reduce the statistics anxiety in students (Blalock, 1987). Since the teacher's anxiety in teaching processes will increase his/her academic performance, it is important for the students to structure the lesson better and be more productive because otherwise, it reduces the quality of the lesson. At the same time, it is thought that this negative attitude towards the statistics course, which is passed from the teacher to the student, will also affect the students' future lives. In addition to the level of anxiety in learning, learning paths supported by the individual's metacognitive awareness skills or the control and planning of these paths are also important for the realization of effective learning. A high level of anxiety control is also a factor that makes learning difficult. The extent to which individuals possess metacognitive skills and characteristics and to what extent these skills are related to statistical anxiety arouses curiosity. Therefore, the research is important to reveal the relationship between statistical anxiety and metacognitive awareness of graduate students studying in the mathematics education program. In addition, when the literature was examined, no studies were conducted with graduate students and in which the variables of statistical anxiety and metacognitive awareness were discussed and examined together. For these reasons, it was necessary to carry out this study. 
In this study, it was aimed to examine the relationships between statistical anxiety and metacognitive awareness levels of graduate students studying in the field of mathematics education and to compare these levels in terms of some variables. In addition, the research will seek answers to the following sub-problems:

1) What are the statistical anxiety levels of the graduate students studying in the mathematics education program?

2) What are the metacognitive awareness levels of the graduate students studying in the mathematics education program?

3) Do the statistical anxiety levels of the graduate students studying in the mathematics education program differ significantly according to the variables of gender, education level, stage of graduate education and taking statistics course?

4) Do the metacognitive awareness levels of the graduate students studying in the mathematics education program differ significantly according to the variables of gender, education level, stage of graduate education and taking statistics course?

5) Is there a significant relationship between statistical anxiety levels and metacognitive awareness levels of the graduate students studying in the mathematics education program?

\section{Material and Methods}

A relational screening model was used in the research. The relational screening model was used to determine the relationship between two or more variables and the level of this relationship (Creswell, 2003). No intervention was made to the group with which the research was conducted, and the existing situation was tried to be described as it was. The study aimed to examine the relationships between statistical anxiety and metacognitive awareness levels of students and to compare these levels in terms of some variables.

\subsection{Study Group}

The research participants consisted of 101 students studying at master's and doctorate levels in the department of mathematics education affiliated to the Educational Sciences, and Science Institutes of the universities in the Central Anatolia, Eastern Black Sea and Marmara regions voluntarily participated in the research. The study group was selected by a convenient sampling method. The demographic information of the graduate students studying in the mathematics education program participating in the study is given in Table 1. 
Table 1: Demographic Information about the Students in the Scope of the Research

\begin{tabular}{|l|l|c|c|}
\hline Variable & Category & $\mathbf{f}$ & $\mathbf{\%}$ \\
\hline \multirow{4}{*}{ Gender } & Female & 74 & 73.3 \\
\cline { 2 - 4 } & Male & 27 & 26.7 \\
\cline { 2 - 4 } & Total & 101 & 100 \\
\cline { 2 - 4 } & Master's Degree & 70 & 69.3 \\
\hline \multirow{3}{*}{$\begin{array}{l}\text { Education } \\
\text { Level }\end{array}$} & PhD degree & 31 & 30.7 \\
\cline { 2 - 4 } & Total & 101 & 100 \\
\cline { 2 - 4 } & Master's Degree Course & 57 & 56.4 \\
\hline \multirow{3}{*}{$\begin{array}{l}\text { Stage of Graduate } \\
\text { Education }\end{array}$} & Master's thesis & 13 & 12.9 \\
\cline { 2 - 4 } & PhD course & 19 & 18.8 \\
\cline { 2 - 4 } & PhD thesis & 12 & 11.9 \\
\cline { 2 - 4 } & Total & 101 & 100 \\
\hline \multirow{2}{*}{$\begin{array}{l}\text { Status of Taking } \\
\text { Statistics Courses }\end{array}$} & Undergraduate level only & 57 & 56.4 \\
\hline & Undergraduate and Graduate level & 101 & 43.6 \\
\hline & Total & & 100 \\
\hline
\end{tabular}

According to Table 1, 73.3\% of the students participating in the research were female, and $26.7 \%$ were male. $69.3 \%$ of the students were studying at master's degree, and $30.7 \%$ at $\mathrm{PhD}$ degree, $56.4 \%$ of the participants were in the master's course stage, $12.9 \%$ in the master's thesis stage, $18.8 \%$ in the PhD course stage and $11.9 \%$ in the $\mathrm{PhD}$ thesis stage. $56.4 \%$ of the students participating in the research stated that they took courses related to statistics only at the undergraduate level, and $43.6 \%$ of them both at undergraduate and graduate levels.

\subsection{Data Collection Tools}

As a data collection tool in this research; the "Statistical Anxiety Scale (SAS)", which was developed by Faber et al., (2018) for graduate students and adapted in Turkish by Güler et al., (2019), and the "Metacognitive Awareness Scale (MCAS)", which was developed by Firat- Durdukoca and Arıbaş (2019) for teacher candidates were used. Data were collected online via www.surveey.com between 20 February 2021 and 30 June 2021.

The construct validity of the Statistical Anxiety Scale was examined by applying exploratory factor analysis (EFA) and confirmatory factor analysis (CFA). Both onedimensional and three-dimensional structures were obtained similarly to the results obtained in factor analysis in SAS's original form. Additionally, since the original form of the SAS was prepared with a three-dimensional structure in anxiety, avoidance and emotionality, it was tested in CFA. In the reliability analysis, the Cronbach Alpha internal consistency coefficient was 0.96 for the overall scale; for the anxiety, avoidance and emotionality dimensions, it was found as $0.91,0.83$ and 0.91 , respectively. These results reveal that the Turkish version of the SAS is a valid and reliable measurement tool (Güler et al., 2019). This scale was developed as a four-point Likert scale; I strongly disagree, I agree somewhat, I quite agree, and I completely agree. There is no reverse-scored item. The highest score that can be obtained from this scale is 68, and the lowest score is 17. The Cronbach-Alpha coefficient for the results of the reliability analysis conducted in this 
study was calculated as 0.80 for the anxiety sub-dimension, 0.79 for the avoidance subdimension, 0.75 for the emotionality sub-dimension, and 0.90 for the overall Cronbach's alpha coefficient of the scale. A low score can mean that students have low anxiety about statistics, and a high score can mean high anxiety levels about statistics. Considering that the gap of this scale was calculated with the formula of "range/number of groups to be performed" (Tekin, 1996), the arithmetic mean score gaps based on the evaluation of the data obtained in the research were interpreted as 1.00-1.75; "low anxiety", 1.76-2.50; "moderate (normal) anxiety", 2.51-3.25; "high anxiety", 3.26-4.00; "very high anxiety".

The Metacognitive Awareness Scale, developed by Frrat- Durdukoca and Arıbaş (2019) to determine the metacognitive awareness levels, consists of 18 items and 3 subdimensions: self-awareness, organizational awareness and judgmental awareness. In the reliability analysis of the scale's sub-dimensions, the Cronbach-Alpha coefficients were found to be 0.79 in the sub-dimension of personal awareness, 0.72 in the sub-dimension of organizational awareness, and 0.62 in judgmental awareness. The scale is a five-point Likert type, and the degree of agreement with the items is classified as 1 "never", 2 "rarely", 3 "often", 4 "usually" and 5 "always" (Firat- Durdukoca \& Arıbaş, 2019). In the evaluation of the mean scores of the scale sub-dimensions; 1.00-1.80 "very low", 1.81-2.60 "low", 2.61-3.40 "medium", 3.41-4.20 "high", 4.21-5.00 "very high" values will be taken as criteria. As a result of the reliability analysis made in this study, the Cronbach alpha coefficients were calculated as 0.81 for the sub-dimension of personal awareness, 0.82 for the sub-dimension of organizational awareness, 0.86 for the sub-dimension of judgmental awareness, and 0.92 for the overall Cronbach alpha coefficient of the scale.

\subsection{Data Analysis}

The program SPSS v22 was utilized in data analysis. Normality assumptions were tested to determine the data analysis tests to be used. In the data analysis, descriptive statistics, t-test, ANOVA and Pearson Moments Correlation Coefficient were used. The Scheffe test was used to determine between which groups the difference was in the case of the significance of the F value obtained. Effect sizes were found with eta squared in ANOVA and Cohen's $d$ in t-tests. To interpret the effect value result obtained 0.01: small effect, 0.06: medium effect and 0.14: large effect gaps suggested by Cohen (1988) were used. In the statistical analysis, the level of significance was taken as 0.05 and 0.01 .

\section{Finding}

In this part of the research, depending on the data obtained in the sub-problems, firstly, the statistical anxiety levels and metacognitive awareness of the graduate students in the mathematics education program were determined. Then the statistical anxiety levels and metacognitive awareness were examined according to the variables of gender, education level, stage of graduate education and taking a statistics course. Finally, the findings regarding the relationship between statistical anxiety and metacognitive awareness of graduate students in the mathematics education program were included. 


\subsection{Findings Related to Statistical Anxiety and Metacognitive Awareness Levels of Graduate Students in Mathematics Education Program}

Table 2: Mean Statistical Anxiety Scores and Standard Deviation Results of Graduate Students Studying in Mathematics Education Program

\begin{tabular}{|c|c|c|c|}
\hline \multicolumn{4}{|l|}{ SAS Items } \\
\hline Anxiety & $\mathbf{N}$ & $\overline{\bar{X}}$ & $S$ \\
\hline $\begin{array}{l}\text { I find it difficult to meet the statistical requirements of the } \\
\text { graduate program I am enrolled in. }\end{array}$ & 101 & 2.84 & .880 \\
\hline $\begin{array}{l}\text { It is difficult for me to discuss statistical content in my } \\
\text { studies adequately. }\end{array}$ & 101 & 2.72 & .680 \\
\hline $\begin{array}{l}\text { I find it difficult to understand the statistical content in } \\
\text { the courses. }\end{array}$ & 101 & 2.66 & .697 \\
\hline $\begin{array}{l}\text { I'm afraid of being funny when I have to interpret statistical } \\
\text { data in a course. }\end{array}$ & 101 & 2.53 & .742 \\
\hline $\begin{array}{l}\text { When I have to present statistical findings in a course, I hope } \\
\text { that no one will ask questions after the presentation. }\end{array}$ & 101 & 2.70 & .922 \\
\hline $\begin{array}{l}\text { I have difficulty presenting a satisfactory report of statistical } \\
\text { research findings. }\end{array}$ & 101 & 2.63 & .689 \\
\hline $\begin{array}{l}\text { I worry that I will not pass the course even though I have carefully } \\
\text { prepared for a statistics exam. }\end{array}$ & 101 & 2.71 & 1.061 \\
\hline $\begin{array}{l}\text { When I take a statistics course, I worry that I will quickly forget } \\
\text { everything I have learned. }\end{array}$ & 101 & 2.84 & .967 \\
\hline Total & 101 & 2.71 & .542 \\
\hline Avoidance & $\mathbf{N}$ & $\bar{X}$ & $S$ \\
\hline $\begin{array}{l}\text { If possible, I would rather take two other courses than one } \\
\text { statistics course. }\end{array}$ & 101 & 2.38 & 1.130 \\
\hline $\begin{array}{l}\text { When sharing presentation topics in courses, I try to ensure that } \\
\text { I get a topic that does not contain statistics. }\end{array}$ & 101 & 2.07 & .738 \\
\hline $\begin{array}{l}\text { While preparing a presentation, I prefer to exclude the parts } \\
\text { related to statistics from the presentation. }\end{array}$ & 101 & 2.37 & .821 \\
\hline $\begin{array}{l}\text { If possible, I skip statistical tables and graphs in } \\
\text { scientific texts. }\end{array}$ & 101 & 2.31 & .956 \\
\hline Total & 101 & 2.28 & .723 \\
\hline Emotionality & $\mathbf{N}$ & $\overline{\bar{X}}$ & $S$ \\
\hline $\begin{array}{l}\text { I feel very uncomfortable when I have to study a statistical } \\
\text { Problem. }\end{array}$ & 101 & 2.67 & .766 \\
\hline $\begin{array}{l}\text { I get very nervous when asked to explain the tables/graphs in } \\
\text { a research report. }\end{array}$ & 101 & 2.42 & .908 \\
\hline $\begin{array}{l}\text { I have trouble selecting and separating required information from a } \\
\text { table with statistical values. }\end{array}$ & 101 & 2.62 & .719 \\
\hline $\begin{array}{l}\text { I feel very nervous when I have to apply a statistical } \\
\text { formula. }\end{array}$ & 101 & 2.66 & .752 \\
\hline $\begin{array}{l}\text { The thought of having to explain a statistical problem in a } \\
\text { course makes me very nervous. }\end{array}$ & 101 & 2.58 & .791 \\
\hline Total & 101 & 2.59 & .558 \\
\hline General Total & 101 & 2.57 & .528 \\
\hline
\end{tabular}


As can be seen in Table 2, the mean scores of the students studying in the mathematics education program regarding statistical anxiety were at the level of "high anxiety" $\left(X^{-}=2.57\right)$. The mean scores of the sub-dimensions related to the statistical anxiety of the students were respectively; "high anxiety" in the anxiety dimension $\left(X^{-}=2.71\right)$, "normal anxiety" in the avoidance dimension $\left(\mathrm{X}^{-}=2.28\right)$ and "high anxiety" in the emotionality dimension $\left(X^{-}=2.59\right)$.

Table 3: Mean Statistical Anxiety Scores and Standard Deviation Results of Graduate Students Studying in Mathematics Education Program

\begin{tabular}{|l|c|c|c|}
\hline MCAS Items & $\mathbf{N}$ & $\overline{\boldsymbol{X}}$ & $\mathbf{S}$ \\
\hline Self-Awareness & 101 & 4.11 & .747 \\
\hline I am aware of my strengths and weaknesses. & 101 & 3.37 & .745 \\
\hline I rely on my memory to remember the information I have learned. & 101 & 3.71 & .766 \\
\hline While studying a subject, I ask myself what I know and what I do not know. & 101 & 3.57 & .779 \\
\hline Before I start studying a subject, I question the difficulty level of that subject. & 101 & 3.57 & .753 \\
\hline I know what I need to be able to solve a problem successfully. & 101 & 3.20 & .938 \\
\hline I am aware that my study skills are better than my friends. & 101 & 3.60 & 1.001 \\
\hline I ask myself how I can learn a subject best. & 101 & 3.92 & .902 \\
\hline I can develop my strategies to learn a subject. & $\mathbf{1 0 1}$ & $\mathbf{3 . 6 3}$ & $\mathbf{. 5 4 0}$ \\
\hline Total & $\mathbf{N}$ & $\overline{\boldsymbol{X}}$ & $\mathbf{S}$ \\
\hline Organizational Awareness & 101 & 3.51 & .912 \\
\hline I evaluate all alternative solutions to solve a problem I encounter. & 101 & 3.55 & .954 \\
\hline I decide which is the best way to solve a problem. & 101 & 3.65 & .974 \\
\hline I research how much time and resources I will need to complete a given task. & 101 & 4.08 & .845 \\
\hline $\begin{array}{l}\text { I try to establish a relationship between what I just learned and my previous } \\
\text { knowledge. }\end{array}$ & & & \\
\hline $\begin{array}{l}\text { I pause in the process of performing a task and question whether the path I'm } \\
\text { following is correct. }\end{array}$ & 101 & 3.33 & .991 \\
\hline When studying a subject, I ask myself, "how can I study differently". & & & \\
\hline Total & 101 & 3.56 & 1.126 \\
\hline Judgmental Awareness & $\mathbf{1 0 1}$ & $\mathbf{3 . 6 1}$ & $\mathbf{. 6 9 7}$ \\
\hline I ask myself questions to make sure I have learned the things I need to learn. & $\mathbf{N}$ & $\overline{\boldsymbol{X}}$ & $\mathbf{S}$ \\
\hline After solving a problem, I analyze whether I have reviewed all solutions. & 101 & 3.68 & 1.009 \\
\hline After completing a task, I ask myself if there is an easier way to do it. & 101 & 3.15 & 1.169 \\
\hline $\begin{array}{l}\text { When I solve a problem, I think about applying the knowledge I have gained to } \\
\text { different problems. }\end{array}$ & 101 & 3.53 & 1.064 \\
\hline Total & 101 & 3.69 & .903 \\
\hline General Total & $\mathbf{1 0 1}$ & $\mathbf{3 . 5 1}$ & $\mathbf{. 8 7 0}$ \\
\hline & & $\mathbf{3 . 6 0}$ & $\mathbf{. 6 1 2}$ \\
\hline
\end{tabular}

As it can be seen in Table 3, the mean scores of students studying in the mathematics education program regarding their metacognitive awareness were at the "high" level $(\bar{X}=3.60)$. The mean scores of the sub-dimensions related to the metacognitive awareness of students were respectively; "high" in the dimension of self-awareness ( $\bar{X}=3.63)$, "high" in the organizational awareness dimension $(\bar{X}=3.61)$ and "high" in the judgmental awareness dimension $(\overline{\mathrm{X}}=3.51)$. 


\subsection{Findings Regarding the Analysis of Statistical Anxiety Levels of Graduate Students Studying in the Mathematics Education Program According to Some Variables}

Table 4: Independent Samples t-test Analysis of Statistical Anxiety Levels of Graduate Students Studying in Mathematics Education Program Regarding the Gender Variable

\begin{tabular}{|c|c|c|c|c|c|c|}
\hline \multicolumn{2}{|c|}{ Sub-dimensions Gender } & $\overline{\mathbf{X}}$ & S.S & $t$ & $\mathrm{p}$ & $\eta^{2}$ \\
\hline \multirow[t]{2}{*}{ Anxiety } & Female & 2.75 & .572 & \multirow{2}{*}{1.569} & \multirow{2}{*}{0.122} & \multirow{2}{*}{$* *$} \\
\hline & Male & 2.58 & .437 & & & \\
\hline \multirow[t]{2}{*}{ Avoidance } & Female & 2.18 & .702 & \multirow{2}{*}{-2.285} & \multirow{2}{*}{0.024} & \multirow{2}{*}{0.050} \\
\hline & Male & 2.54 & .724 & & & \\
\hline \multirow[t]{2}{*}{ Emotionality } & Female & 2.61 & .602 & \multirow{2}{*}{0.717} & \multirow{2}{*}{0.475} & \multirow{2}{*}{$* *$} \\
\hline & Male & 2.52 & .419 & & & \\
\hline \multirow[t]{2}{*}{ Total } & Female & 2.57 & .552 & \multirow{2}{*}{0.169} & \multirow{2}{*}{0.866} & \multirow{2}{*}{$* *$} \\
\hline & Male & 2.55 & .466 & & & \\
\hline
\end{tabular}

${ }^{*} \mathrm{p}<0.05 * *$ Since there is no significant difference, the effect size was not calculated.

When Table 4 was examined, a statistically significant difference was found in the avoidance sub-dimension when the mean scores of statistical anxiety depending on the gender variable of the graduate students studying in the mathematics education program were examined $(p=0.024<0.05)$. The effect value showing the size of this significant difference was calculated as $\left(\eta^{2 \text { nd }}=0.050\right)$ and determined as a small level effect. When the mean scores were examined, it was seen that this difference was in favor of female students and female students had lower anxiety levels. No statistically significant difference was found between the mean scores of the other sub-dimensions and the gender variable (anxiety $p=0.122>0.05$, emotionality $p=0.475>0.05$ ). When the total mean scores were examined, it was seen that there was no statistically significant difference between the statistical anxiety of the graduate students studying in the mathematics education program and the gender variable $(p=0.866>0.05)$.

Table 5: Independent Samples t-test Analysis of Statistical Anxiety Levels of Graduate Students Studying in Mathematics Education Program Regarding the Gender Variable

\begin{tabular}{|c|c|c|c|c|c|c|}
\hline Sub-Dimensions & Registered Graduate Level & $\overline{\mathbf{X}}$ & S.S & $\mathbf{t}$ & $\mathbf{p}$ & $\eta^{2}$ \\
\hline \multirow[t]{2}{*}{ Anxiety } & Master's Degree & 2.67 & .477 & \multirow{2}{*}{-0.781} & \multirow{2}{*}{0.122} & \multirow{2}{*}{$* *$} \\
\hline & PhD degree & 2.77 & .672 & & & \\
\hline \multirow[t]{2}{*}{ Avoidance } & Master's Degree & 2.11 & .679 & \multirow{2}{*}{-3.663} & \multirow{2}{*}{0.000} & \multirow{2}{*}{0.079} \\
\hline & PhD degree & 2.65 & .688 & & & \\
\hline \multirow{2}{*}{ Emotionality } & Master's Degree & 2.54 & .538 & \multirow{2}{*}{-1.179} & \multirow{2}{*}{0.241} & \multirow{2}{*}{$* *$} \\
\hline & PhD degree & 2.69 & .599 & & & \\
\hline \multirow[t]{2}{*}{ Total } & Master's Degree & 2.50 & .461 & \multirow{2}{*}{-1.969} & \multirow{2}{*}{0.046} & \multirow{2}{*}{0.037} \\
\hline & PhD degree & 2.71 & .639 & & & \\
\hline
\end{tabular}

${ }^{*} \mathrm{p}<0.05{ }^{* *}$ Since there is no significant difference, the effect size was not calculated.

When Table 5 was examined, a statistically significant difference was found in the avoidance sub-dimension when the mean scores of statistical anxiety depending on the 
gender variable of the graduate students studying in the mathematics education program were examined $(p=0.000<0.05)$. The effect value showing the size of this significant difference was calculated as $\left(\eta^{2 n d}=0.079\right)$ and determined as a small level effect. When the mean scores were examined, it was seen that this difference was in favor of master's degree students, and these students had lower anxiety levels. No statistically significant difference was found between the mean scores of the other sub-dimensions and the gender variable (anxiety $p=0.122>0.05$, emotionality $p=0.241>0.05$ ). When the total mean scores were analyzed, it was seen that there was a statistically significant difference between the statistical anxiety of graduate students studying in the mathematics teaching program and the variable of education level $(p=0.046<0.05)$. The effect value showing the size of this significant difference was calculated as $\left(\eta^{2}=0.037\right)$ and determined as a small level effect. When the mean scores were examined, it was seen that this difference was in favor of master's degree students, and these students had lower anxiety levels.

Table 6: ANOVA Analysis of Statistical Anxiety Levels of Graduate Students Studying in Mathematics Education Program on the Variable of Graduate Education Stage

\begin{tabular}{|c|c|c|c|c|c|c|c|}
\hline Sub-Dimensions & $\begin{array}{l}\text { Graduate Education } \\
\text { Stage }\end{array}$ & $\overline{\mathbf{X}}$ & S.S & $\mathbf{F}$ & p & Difference & $\eta 2$ \\
\hline \multirow[t]{4}{*}{ Anxiety } & Master's Degree Course & 2.68 & .473 & \multirow{4}{*}{1.664} & \multirow{4}{*}{.180} & & \multirow{4}{*}{$* *$} \\
\hline & Master's thesis & 2.63 & .511 & & & & \\
\hline & PhD course & 2.61 & .572 & & & & \\
\hline & PhD thesis & 3.02 & .764 & & & & \\
\hline \multirow[t]{4}{*}{ Avoidance } & Master's Degree Course & 2.17 & .720 & \multirow{4}{*}{5.784} & \multirow{4}{*}{$.001^{*}$} & Master's thesis* & \multirow{4}{*}{0.152} \\
\hline & Master's thesis & 1.82 & .344 & & & PhD course & \\
\hline & PhD course & 2.56 & .622 & & & Master's thesis* & \\
\hline & PhD thesis & 2.79 & .789 & & & PhD thesis & \\
\hline \multirow[t]{4}{*}{ Emotionality } & Master's Degree Course & 2.56 & .505 & \multirow{4}{*}{1.128} & \multirow{4}{*}{.342} & & \multirow{4}{*}{$* *$} \\
\hline & Master's thesis & 2.46 & .680 & & & & \\
\hline & PhD course & 2.58 & .424 & & & & \\
\hline & PhD thesis & 2.85 & .800 & & & & \\
\hline \multirow{4}{*}{ Total } & Master's Degree Course & 2.53 & .469 & \multirow{4}{*}{2.603} & \multirow{4}{*}{$.042^{*}$} & \multirow{4}{*}{$\begin{array}{l}\text { Master's thesis* } \\
\text { PhD thesis }\end{array}$} & \multirow{4}{*}{0.069} \\
\hline & Master's thesis & 2.39 & .423 & & & & \\
\hline & PhD course & 2.59 & .532 & & & & \\
\hline & PhD thesis & 2.91 & .763 & & & & \\
\hline
\end{tabular}

${ }^{*} \mathrm{p}<0.05{ }^{* *}$ Since there is no significant difference, the effect size was not calculated.

When Table 6 was examined, a statistically significant difference was found in the avoidance sub-dimension when the mean scores of statistical anxiety of the graduate students studying in the mathematics education program depending on the gender variable were examined $(\mathrm{p}=0.001<0.05)$. When the results of the Scheffe test performed to determine the difference between the groups were examined, it was seen that this difference was in favor of the group that was at the master's thesis stage in graduate education between the group that was in the master's thesis stage and the PhD course stage and between the group that was in the master's thesis stage and the PhD thesis stage. No statistically significant difference was found between the mean scores of the 
other sub-dimensions and the variable of the students' graduate education stage (anxiety $p=0.180>0.05$, emotionality $p=0.342>0.05$ ). When the total mean scores were examined, it was observed that there was a statistically significant difference between the statistical anxiety of graduate students studying in the mathematics teaching program and the variable of the graduate education stage $(\mathrm{p}=0.042<0.05)$. When the results of the Scheffe test performed to determine the difference between the groups were examined, it was determined that this difference was in favor of the group in the master thesis stage between the master's thesis stage and the PhD course stage. It was determined that the effect size values of the dimensions with a significant difference regarding the variable of the graduate education stage were at the high effect level in the avoidance dimension ( $\eta 2$ $=0.152)$ and at the medium effect level in the total of the scale $(\eta 2=0.069)$.

Table 7: Independent Samples t-test Analysis of Statistical Anxiety Levels of Graduate Students Studying in Mathematics Education Program Regarding the Taking Statistics Course Before

\begin{tabular}{|c|c|c|c|c|c|}
\hline \multicolumn{2}{|c|}{ Sub dimensions Status of Taking Statistics Courses } & $\overline{\mathbf{X}}$ & S.S & $\mathbf{t}$ & $\mathbf{p}$ \\
\hline \multirow[t]{2}{*}{ Anxiety } & I only took a statistics course at the graduate level & 2.63 & .487 & \multirow[b]{2}{*}{-1.452} & \multirow[b]{2}{*}{0.150} \\
\hline & $\begin{array}{l}\text { I took statistics courses at both undergraduate and } \\
\text { graduate levels. }\end{array}$ & 2.79 & 601 & & \\
\hline \multirow[t]{2}{*}{ Avoidance } & I only took a statistics course at the graduate level & 2.25 & .610 & \multirow[b]{2}{*}{-0.330} & \multirow[b]{2}{*}{0.742} \\
\hline & $\begin{array}{l}\text { I took statistics courses at both undergraduate and } \\
\text { graduate levels. }\end{array}$ & 2.30 & .853 & & \\
\hline \multirow[t]{2}{*}{ Emotionality } & I only took a statistics course at the graduate level & 2.54 & .499 & \multirow[b]{2}{*}{-0.981} & \multirow[b]{2}{*}{0.326} \\
\hline & $\begin{array}{l}\text { I took statistics courses at both undergraduate and } \\
\text { graduate levels. }\end{array}$ & 2.65 & 627 & & \\
\hline \multirow[t]{2}{*}{ Total } & I only took a statistics course at the graduate level & 2.52 & .467 & \multirow[b]{2}{*}{-1.113} & \multirow[b]{2}{*}{0.269} \\
\hline & $\begin{array}{l}\text { I took statistics courses at both undergraduate and } \\
\text { graduate levels. }\end{array}$ & 2.63 & .597 & & \\
\hline
\end{tabular}

${ }^{*} \mathrm{p}<0.05$

When Table 7 was examined, a statistically significant difference was not found in all subdimensions and in total when the statistical anxiety mean scores of the students studying in the mathematics education program were examined depending on the variable of taking statistics course before (anxiety $p=0.150>0.05$, avoidance $p=0.742>, 0.05$ emotionality $p=0.326>0.05$, total $p=0.269>0.05)$. When the mean scores were examined, it was seen that the students who took statistics courses at both undergraduate and graduate levels had a higher level of anxiety. 
3.3 Findings Regarding the Analysis of Metacognitive Awareness Levels of Graduate Students Studying in the Mathematics Education Program According to Some Variables

Table 8: Independent Samples t-test Analysis of Metacognitive Awareness Levels of Graduate Students Studying in Mathematics Education Program Regarding the Gender Variable

\begin{tabular}{|l|l|c|c|c|c|}
\hline Sub-Dimensions Gender & \multicolumn{1}{c}{} & $\overline{\mathbf{X}}$ & $\mathbf{S . S}$ & $\mathbf{T}$ & $\mathbf{P}$ \\
\hline \multirow{2}{*}{ Self-Awareness } & Female & 3.67 & .543 & \multirow{2}{*}{1.44} & \multirow{2}{*}{0.152} \\
\cline { 2 - 5 } & Male & 3.50 & .518 & & \\
\hline \multirow{2}{*}{ Organizational Awareness } & Female & 3.60 & .746 & \multirow{2}{*}{0.229} & \multirow{2}{*}{0.819} \\
\cline { 2 - 4 } & Male & 3.64 & .552 & & \multirow{2}{*}{0.128} \\
\hline \multirow{2}{*}{ Judgmental Awareness } & Female & 3.59 & .847 & \multirow{2}{*}{0.535} & \multirow{2}{*}{0.956} \\
\cline { 2 - 4 } & Male & 3.29 & .909 & \multirow{2}{*}{0.341} \\
\hline
\end{tabular}

*p. $<0.05$

When Table 8 was examined, a statistically significant difference was not found in all subdimensions and in total when the mean scores of metacognitive awareness of the graduate students studying in the mathematics education program were examined depending on the gender variable (self-awareness $\mathrm{p}=0.152>0.05$, organizational $\mathrm{p}=0.819>0.05$, judgmental $\mathrm{p}=0.128>0.05$, total $\mathrm{p}=0.341>0.05)$.

Table 9: Independent Samples t-test Analysis of the Metacognitive

Awareness Levels of the Graduate Students Studying in the Mathematics

Education Program Related to the Education Level Variable

\begin{tabular}{|c|c|c|c|c|c|c|}
\hline Sub-Dimensions & Education Level & $\overline{\mathbf{X}}$ & S.S & $\mathbf{t}$ & $p$ & $\eta 2$ \\
\hline \multirow[t]{2}{*}{ Self-Awareness } & Master's Degree & 3.73 & .545 & \multirow{2}{*}{3.013} & \multirow{2}{*}{0.006} & \multirow{2}{*}{0.063} \\
\hline & PhD Degree & 3.41 & .464 & & & \\
\hline \multirow[t]{2}{*}{ Organizational Awareness } & Master's Degree & 3.72 & .681 & \multirow{2}{*}{2.522} & \multirow{2}{*}{0.014} & \multirow{2}{*}{0.053} \\
\hline & PhD Degree & 3.36 & .675 & & & \\
\hline \multirow[t]{2}{*}{ Judgmental Awareness } & Master's Degree & 3.57 & .763 & \multirow{2}{*}{1.107} & \multirow{2}{*}{0.271} & \multirow{2}{*}{$* *$} \\
\hline & PhD Degree & 3.37 & 1.074 & & & \\
\hline \multirow[t]{2}{*}{ Total } & Master's Degree & 3.69 & .586 & \multirow{2}{*}{2.407} & \multirow{2}{*}{0.018} & \multirow{2}{*}{0.051} \\
\hline & PhD Degree & 3.38 & .624 & & & \\
\hline
\end{tabular}

${ }^{*} \mathrm{p}<0.05^{* *}$ Since there is no significant difference, the effect size was not calculated.

When Table 9 was examined, a statistically significant difference was found in the subdimensions of self-awareness and organizational awareness when the metacognitive awareness mean scores of the graduate students studying in the mathematics education program were examined depending on the education level variable (Self-awareness $p=0.006<0.05$, Organizational awareness $p=0.014) .<0.05)$. When the mean scores were examined, it was seen that this difference was in favor of students at the master's degree level. No statistically significant difference was found between the mean scores of judgmental awareness and the education level variable $(p=0.271>0.05)$. When the total 
mean scores were analyzed, it was seen that there was a statistically significant difference between the metacognitive awareness of graduate students studying in the mathematics teaching program and the variable of education level $(\mathrm{p}=0.018<0.05)$. When the mean scores were examined, it was seen that this difference was in favor of the master's degree students. It was determined that the effect size values related to the education level variable of the dimensions with a significant difference were at the medium effect level in the self-awareness dimension $(\eta 2=0.063)$, at the small effect level in the organizational awareness dimension $(\eta 2=0.053)$, and the small effect level in the total $(\eta 2=0.051)$.

Table 10: ANOVA Analysis of Metacognitive Awareness Levels of Graduate Students Studying in Mathematics Education Program on the Variable of Graduate Education Stage

\begin{tabular}{|c|c|c|c|c|c|c|c|}
\hline \multicolumn{2}{|c|}{$\begin{array}{l}\text { Sub-Dimensions Graduate Education } \\
\text { Stage }\end{array}$} & $\overline{\mathbf{X}}$ & S.S & $\mathbf{F}$ & $\mathbf{P}$ & Difference & $\eta 2$ \\
\hline \multirow[t]{4}{*}{$\begin{array}{l}\text { Self } \\
\text { Awareness }\end{array}$} & $\begin{array}{l}\text { Master's Degree } \\
\text { Course }\end{array}$ & 3.60 & 0.492 & \multirow{4}{*}{9.949} & \multirow{4}{*}{.000} & \multirow{4}{*}{$\begin{array}{l}\text { Master's thesis* } \\
\text { Master's course } \\
\text { Master's thesis * } \\
\text { PhD course } \\
\text { Master's thesis* } \\
\text { PhD thesis }\end{array}$} & \multirow{4}{*}{0.235} \\
\hline & $\begin{array}{l}\text { Master's } \\
\text { thesis }\end{array}$ & 4.26 & 0.438 & & & & \\
\hline & $\begin{array}{l}\text { PhD } \\
\text { course }\end{array}$ & 3.38 & 0.462 & & & & \\
\hline & $\begin{array}{l}\text { PhD } \\
\text { thesis }\end{array}$ & 3.45 & 0.483 & & & & \\
\hline \multirow[t]{4}{*}{$\begin{array}{l}\text { Organizational } \\
\text { Awareness }\end{array}$} & $\begin{array}{l}\text { Master's Degree } \\
\text { Course }\end{array}$ & 3.55 & 0.578 & \multirow{4}{*}{13.597} & \multirow{4}{*}{.000} & \multirow{4}{*}{$\begin{array}{l}\text { Master's thesis* } \\
\text { Master's course } \\
\text { Master's thesis * } \\
\text { PhD course } \\
\text { Master's thesis* } \\
\text { PhD thesis }\end{array}$} & \multirow{4}{*}{0.296} \\
\hline & $\begin{array}{l}\text { Master's } \\
\text { thesis }\end{array}$ & 4.50 & 0.565 & & & & \\
\hline & $\begin{array}{l}\text { PhD } \\
\text { course }\end{array}$ & 3.56 & 0.664 & & & & \\
\hline & $\begin{array}{l}\text { PhD } \\
\text { thesis }\end{array}$ & 3.04 & 0.582 & & & & \\
\hline \multirow[t]{4}{*}{$\begin{array}{l}\text { Judgmental } \\
\text { Awareness }\end{array}$} & $\begin{array}{l}\text { Master's Degree } \\
\text { Course }\end{array}$ & 3.38 & 0.619 & \multirow{4}{*}{6.641} & \multirow{4}{*}{.000} & \multirow{4}{*}{$\begin{array}{l}\text { Master's thesis* } \\
\text { Master's course } \\
\text { Master's thesis* } \\
\text { PhD course } \\
\text { Master's thesis* } \\
\text { PhD thesis }\end{array}$} & \multirow{4}{*}{0.170} \\
\hline & $\begin{array}{l}\text { Master's } \\
\text { thesis }\end{array}$ & 4.44 & 0.751 & & & & \\
\hline & $\begin{array}{l}\text { PhD } \\
\text { course }\end{array}$ & 3.40 & 1.351 & & & & \\
\hline & $\begin{array}{l}\mathrm{PhD} \\
\text { thesis }\end{array}$ & 3.31 & 0.386 & & & & \\
\hline \multirow[t]{4}{*}{ Total } & $\begin{array}{l}\text { Master's Degree } \\
\text { Course }\end{array}$ & 3.53 & 0.484 & \multirow{4}{*}{11.480} & \multirow{4}{*}{.000} & \multirow{4}{*}{$\begin{array}{l}\text { Master's thesis* } \\
\text { Master's course } \\
\text { Master's thesis * } \\
\text { PhD course } \\
\text { Master's thesis* } \\
\text { PhD thesis }\end{array}$} & \multirow{4}{*}{0.262} \\
\hline & $\begin{array}{l}\text { Master's } \\
\text { thesis }\end{array}$ & 4.38 & 0.505 & & & & \\
\hline & $\begin{array}{l}\text { PhD } \\
\text { course }\end{array}$ & 3.44 & 0.701 & & & & \\
\hline & $\begin{array}{l}\text { PhD } \\
\text { thesis }\end{array}$ & 3.28 & 0.489 & & & & \\
\hline
\end{tabular}

${ }^{*} \mathrm{p} .<0.05$ 
When Table 10 was examined, a statistically significant difference was found in the subdimensions of self-awareness, organizational awareness, and judgmental awareness when the metacognitive awareness mean scores of the graduate students studying in the mathematics education program were examined depending on the variable of the graduate education stage (self-awareness $p=0.000<0.05$, organizational awareness $\mathrm{p}=0.000<0.05$, judgmental awareness $\mathrm{p}=0.000<0.05$ ). When the results of the Scheffe test performed to determine the difference between the groups were examined, it was seen that this difference was in favor of the group that was in the master's thesis stage in all sub-dimensions, between the master's thesis and the master's course, the master's thesis and the PhD course, and the master's thesis and the PhD thesis.

When the total mean scores were examined, it was seen that there was a statistically significant difference between the metacognitive awareness of the graduate students studying in the mathematics education program and the variable of the graduate education stage $(p=0.000<0.05)$. When the results of the Scheffe test performed to determine the difference between the groups were examined, it was determined that this difference was in favor of the group that was at the master's thesis between the master's degree thesis and the master's course, the master's thesis and the PhD course, and the master's thesis and the $\mathrm{PhD}$ thesis. The effect size values of the factors with significant difference related to the graduate education stage variable were determined the high effect level in the self-awareness factor $\left(\eta^{2}=0.235\right)$, high effect level in the organizational awareness factor $\left(\eta^{2}=0.296\right)$, high effect level in the judgmental awareness factor $\left(\eta^{2}=0.170\right)$ and high effect level in the total of the scale $\left(\eta^{2}=0.262\right)$.

Table 11: Independent Samples t-test Analysis of Metacognitive Awareness Levels of Graduate Students Studying in Mathematics Education Program Regarding the Taking Statistics Course Variable

\begin{tabular}{|c|c|c|c|c|c|}
\hline \multicolumn{2}{|c|}{ Sub dimensions Taking Statistics Courses } & \multirow{2}{*}{$\begin{array}{c}\overline{\mathbf{X}} \\
3.62\end{array}$} & \multirow{2}{*}{$\begin{array}{l}\text { S.S } \\
.508\end{array}$} & \multirow{3}{*}{$\begin{array}{l}\mathbf{t} \\
-0.156\end{array}$} & \multirow{3}{*}{\begin{tabular}{|l|}
$\mathbf{p}$ \\
0.876
\end{tabular}} \\
\hline \multirow[t]{2}{*}{ Self-Awareness } & $\begin{array}{l}\text { I only took a statistics course } \\
\text { at the graduate level. }\end{array}$ & & & & \\
\hline & $\begin{array}{l}\text { I took statistics courses at both } \\
\text { undergraduate and graduate levels. }\end{array}$ & 3.64 & .584 & & \\
\hline \multirow[t]{2}{*}{$\begin{array}{l}\text { Organizational } \\
\text { Awareness }\end{array}$} & $\begin{array}{l}\text { I only took a statistics course at } \\
\text { the graduate level. }\end{array}$ & 3.50 & .558 & \multirow{2}{*}{-1.899} & \multirow{2}{*}{0.072} \\
\hline & $\begin{array}{l}\text { I took statistics courses at both } \\
\text { undergraduate and graduate levels. }\end{array}$ & 3.75 & .830 & & \\
\hline \multirow[t]{2}{*}{$\begin{array}{l}\text { Judgmental } \\
\text { Awareness }\end{array}$} & $\begin{array}{l}\text { I only took a statistics course } \\
\text { at the graduate level. }\end{array}$ & 3.40 & .628 & \multirow{2}{*}{-1.472} & \multirow{2}{*}{0.144} \\
\hline & $\begin{array}{l}\text { I took statistics courses at both } \\
\text { undergraduate and graduate levels. }\end{array}$ & 3.65 & 1.099 & & \\
\hline \multirow[t]{2}{*}{ Total } & $\begin{array}{l}\text { I only took a statistics course } \\
\text { at the graduate level. }\end{array}$ & 3.53 & .479 & \multirow{2}{*}{-1.209} & \multirow{2}{*}{0.230} \\
\hline & $\begin{array}{l}\text { I took statistics courses at } \\
\text { both undergraduate and graduate levels. }\end{array}$ & 3.68 & .748 & & \\
\hline
\end{tabular}

${ }^{*}$ p. $<0.05$ 
When Table 11 was examined, a statistically significant difference was not found in all sub-dimensions and in total when the mean scores of metacognitive awareness of the graduate students studying in the mathematics education program were examined depending on the taking statistics course variable (self-awareness $p=0.876>0.05$, organizational $\mathrm{p}=0.072>0.05$, judgmental $\mathrm{p}=0.144>0.05$, total $\mathrm{p}=0.230>0.05$ ). When the mean scores were examined, it was seen that the students who took statistics courses at both undergraduate and graduate levels had a higher level of metacognitive awareness.

\subsection{Findings Related to the Relationship Between Statistical Anxiety and Metacognitive Awareness of Graduate Students Studying in the Mathematics Education Program}

Table 12: Correlation Results between Statistical Anxiety and Metacognitive Awareness of Graduate Students Studying in Mathematics Education Program

\begin{tabular}{|c|c|c|c|c|c|}
\hline $\begin{array}{l}\text { Statistics Anxiety } \\
\text { Sub-Dimensions }\end{array}$ & $\begin{array}{c}\text { MCAS } \\
\text { Sub - } \\
\text { dimensions } \\
\end{array}$ & $\begin{array}{c}\text { Self- } \\
\text { Awareness }\end{array}$ & $\begin{array}{c}\text { Organizational } \\
\text { Awareness }\end{array}$ & $\begin{array}{c}\text { Judgmental } \\
\text { Awareness }\end{array}$ & $\begin{array}{c}\text { Total } \\
\text { Metacognitive } \\
\text { Awareness }\end{array}$ \\
\hline \multirow[t]{2}{*}{ Anxiety } & $r$ & $-0.500^{* *}$ & $-0.495^{* *}$ & $-0.495^{* *}$ & \\
\hline & $\mathrm{p}$ & 0.000 & 0.000 & 0.000 & \\
\hline \multirow[t]{2}{*}{ Avoidance } & $\mathrm{r}$ & $-0.443^{* *}$ & $-0,419^{* *}$ & $-0.482^{* *}$ & \\
\hline & $\mathrm{p}$ & 0.000 & 0.000 & 0.000 & \\
\hline \multirow[t]{2}{*}{ Emotionality } & $\mathrm{r}$ & $-0.436^{* *}$ & $-0.450^{* *}$ & $-0.424^{* *}$ & \\
\hline & $\mathrm{p}$ & 0.000 & 0.000 & 0.000 & \\
\hline \multirow{2}{*}{$\begin{array}{l}\text { Total Statistics } \\
\text { Anxiety }\end{array}$} & $\mathrm{r}$ & & & & $-0.564^{* *}$ \\
\hline & $\mathrm{p}$ & & & & 0.000 \\
\hline
\end{tabular}

** $\mathrm{p}<0.01$

When Table 12 was examined, it was seen that there was a moderately significant negative correlation between all dimensions of the metacognitive awareness scale and all dimensions of the statistical anxiety scale applied to graduate students studying in the mathematics education program. When the results were examined in detail, the correlation values between the anxiety sub-dimension of statistical anxiety and selfawareness, organizational awareness and judgmental awareness were found respectively $\left(\mathrm{r}=-0.500^{* *},-0.495^{* *},-0.495^{* *}\right)$, correlation values between avoidance sub-dimension and self-awareness, organizational awareness and judgmental awareness $\left(r=-0.443^{* *}\right.$,$\left.0.419^{* *},-0.482^{* *}\right)$, the correlation values between emotionality sub-dimension and selfawareness, organizational awareness and judgmental awareness $\left(\mathrm{r}=-0.436^{* *},-0.450^{* *}\right.$, $0.424^{* *}$ ). It was determined that there was a moderately significant negative relationship between their total statistical anxiety and their total metacognitive awareness $(\mathrm{r}=-0.564$, $\mathrm{p}=.000)$. 


\section{Conclusion and Discussion}

In this study, it was aimed to examine the statistical anxiety and metacognitive awareness levels of graduate students studying in the mathematics education program and the relationship between them. In addition, it was also examined whether the students' statistical anxiety and metacognitive awareness differed according to the variables of gender, education level, graduate education stage, and taking a statistics course.

Considering the mean scores obtained from the statistical anxiety scale in the study, it was seen that the graduate students studying in the mathematics education program had a high level of statistical anxiety in the anxiety and emotionality subdimensions, normal level in the avoidance sub-dimension, and generally high level in statistical anxiety. This result supports the studies in the literature (Baloğlu, 2003; Baloğlu \& Zelhart, 2004; Primi \& Chiesi, 2018; Roberts \& Saxe, 1982;). When the mean scores of the students obtained from the metacognitive awareness scale were examined, it was seen that they had a high level of metacognitive awareness in all sub-dimensions and in general. This result obtained from the research is similar to the studies in the literature (Aykut et al., 2016; Özsoy et al., 2010).

The study examined the statistical anxiety levels of graduate students studying in the mathematics education program in terms of variables such as gender, education level, graduate education stage, and taking a statistics course. As a result of the research, it was concluded that the statistical anxiety levels of the students did not change according to the gender variable. A statistically significant difference was found only in the avoidance sub-dimension. When the mean scores were examined, it was seen that this difference was in favor of female students and female students had lower anxiety levels. Different findings were obtained in the studies performed to determine the effect of gender variable on statistical anxiety. In Sutarso's (1992) study, it was determined that there was no significant difference between the statistical anxiety of male and female students; in the studies conducted by Benson (1989), Baloğlu (2003), and Rodarte-Luna and Sherry (2008), it was determined that the statistical anxiety of female students was significantly higher than that of males.

In this study, students' statistical anxiety levels differed statistically significantly in the avoidance sub-dimension and total, according to the variables of graduate education level and graduate education stage. This finding is similar to the result obtained from the studies of Büyüköztürk (1997) and Saracaloglu et al., (2005). When the results were examined, it was seen that PhD students had higher anxiety levels than graduate students, and students at the PhD thesis stage had a similarly higher level of statistical anxiety than the students at other stages. This situation can be interpreted as the increase in statistical anxiety as the academic level rises, and the intensity of statistical knowledge and methods on the subjects studied increases the anxiety.

According to the findings of this study, there was no statistically significant difference in all sub-dimensions and in total when the statistical anxiety mean scores of the graduate students studying in the mathematics education program were examined 
depending on the variable of taking a statistics course. In this case, it can be said that statistics anxiety and taking a statistics course are not related. When the findings were examined, it was seen that the students who took a statistics course at both undergraduate and graduate levels had a higher anxiety level, unlike the students who only took a statistics course at the graduate level. This result is similar to the result of Saracaloğlu (2008) and Aslan and Karagül's (2016) studies that anxiety levels about doing research do not differ significantly according to taking courses.

No statistically significant difference was found in students' metacognitive awareness levels according to gender in the study. This result is similar to some studies in the literature (Memnun and Akkaya, 2009; Öztürk and Kurtuluş, 2017). However, there are studies in the literature stating that gender is an important predictor of metacognitive awareness levels contrary to this situation and in some studies in the literature, there are research results showing that female students (Alc1 and Altun, 2007 Gül et al., 2015) or male students (Gürefe, 2015; Memiş and Arıcan, 2013) have a higher level of metacognitive awareness.

In this study, a statistically significant difference was found in the metacognitive awareness levels of the students, in the sub-dimensions of self-awareness, organizational awareness and total according to their graduate education levels. When the mean scores were examined, it was seen that this difference was in favor of students at the master's degree level. This result is in line with the result of the study of Irak et al., (2015) that the level of metacognitive awareness differs according to the education level. A statistically significant difference was found in all sub-dimensions and in total when the metacognitive awareness mean scores of the graduate students studying in the mathematics education program were examined depending on the variable of the graduate education stage. When the results were examined, it was seen that the students in the master's thesis stage had a higher level of metacognitive awareness. This is an unexpected situation contrary to the thought that metacognitive awareness will increase as the education level increases. Why PhD students do not have higher metacognitive awareness levels than graduate students should be examined in detail in a separate study. The relationship between statistical anxiety and metacognitive awareness of graduate students studying in a mathematics education program was examined in the study. It was determined that there was a negative and moderately significant relationship between these variables. In other words, it can be said that as the metacognitive awareness of the students increases, their statistical anxiety decreases or as their statistical anxiety increases, their metacognitive awareness decreases. In their study, Öztürk and Serin (2020) stated that as the metacognitive awareness levels of teacher candidates increase, their anxiety towards mathematics and, therefore, their anxiety towards teaching decreases. These results show parallelism with the research findings. Kaçar and Sarıçam (2015), Gökbulut and Akdağ (2016) stated in their studies that there is a positive relationship between mathematics anxiety and metacognitive awareness levels of primary school teacher candidates. Although the type of anxiety examined in our research is statistical anxiety, statistics can be evaluated as a branch of mathematics in 
this context. Everson et al., (1994) stated that individuals with low anxiety levels could use their metacognition positively and thus perform better than individuals with high anxiety, and in times of high anxiety, metacognition affects more negatively, and thus results in poor performance. Contrary to this situation, Wells and Matthews (1996), Spada et al., (2010), Irak (2012), Gargabi et al., (2014) and Savaşan (2019), saw in their studies that there are significant positive relationships between anxiety and metacognitive awareness. Everson et al. (1994) suggested that individuals with high metacognitive awareness, who pay close attention to their thinking processes, show high anxiety and cause a decrease in their performance. They stated that high anxiety and high metacognition show the worst performance, so if an individual is too aware of metacognition, his/her excessive metacognition (negative metacognition) may lead the individual to failure due to a high anxiety level in a given task.

When we think of metacognitive awareness as a system that controls what a person knows and does not know, it means that the person does not have anxiety or is less anxious about the situation s/he is aware of. The more people are aware of their knowledge, and the better they use it. Most importantly, if they are aware of their deficiencies, their negative attitudes, such as anxiety towards the situation or the lesson, are expected to decrease. From this point of view, it can be said that anxiety is also a negative attitude and situations that affect this attitude can directly affect anxiety. Therefore, it can be concluded that increasing metacognitive awareness will reduce anxiety; in other words, individuals with high levels of metacognitive awareness have less anxiety. Studies have shown that having metacognitive awareness skills improves attitudes towards the lesson in a positive way (Akdur, 1996; Gelen, 2004; Küçük-Özcan, 2000; Manning and Payne, 1996).

Future studies can determine whether there are significant relationships between the statistical anxiety of students who continue their graduate education in different fields and variables that are not addressed in this study. In addition, quantitative data can be supported by the findings obtained from the analyzes by conducting more detailed and in-depth qualitative research to determine the reasons for students' anxiety towards statistics. And most importantly, why PhD students have less metacognitive awareness and more anxiety than graduate students should be examined in detail.

\section{Conflict of Interest Statement}

The authors declare that they have no conflict of interest related to the study or preparation of the manuscript.

\section{About the Authors}

Murat Altun has been working as a Professor Doctor at Department of Mathematics Education Faculty of Education at Bursa Uludağ University in Turkey.

Gül Kaleli Yılmaz has been working as an Associated Professor Doctor at Department of Mathematics Education Faculty of Education at Bursa Uludağ University in Turkey. Her research is mainly on technological pedagogical content knowledge, mathematics 
and geometry education. She has journal articles published in international and national indexes, book chapters and papers presented to international meetings.

Baris Demir is lecturer at Kocaeli University Hereke Omer Ismet Uzunyol Vocational School and PhD student at Bursa Uludag University Mathematics Education. His academic interests are mathematics education and mathematical modeling. He has articles and presentations on these topics.

Hulya Sert Çelik is a mathematics teacher at a secondary school affiliated to national education and a doctoral student at Bursa Uludag University. Her academic interests are mathematics and geometry education. She has articles and presentations on these topics.

\section{References}

Akdur, T. E. (1996). Effect of collaborative computer-based concept mapping on students' physics achievement, attitude toward physics, attitude toward concept mapping and metacognitive skills at high school level. (Unpublished master's thesis). Middle East Technical University.

Alcı, B. \& Altun, S. (2007). Lise öğrencilerinin matematik dersine yönelik özdüzenleme ve bilişüstü becerileri, cinsiyete, sınıfa ve alanlara göre farklılaşmakta mıdır?. Çukurova

Üniversitesi Sosyal Bilimler Enstitüsü Dergisi,16(1), 33-44. Retrieved from https://dergipark.org.tr/tr/pub/cusosbil/issue/4376/59934.

Altun, M. (2018). Teaching mathematics in secondary schools. Bursa: Alfa Aktüel.

Aslan, C. (2010). Türkçe eğitimi programlarında lisansüstü öğrenim gören öğrencilerinakademik özyeterliklerine ilişkin görüşleri [The opinions of the turkish education postgraduate students about their academic selfefficacy]. Mehmet Akif Ersoy University Journal of Education Faculty, 0 (19), 87115. Retrieved from https://dergipark.org.tr/tr/pub/maeuefd/issue/19391/205944.

Aykut, Ç., Karasu, N. \& Kaplan, G. (2016). Özel eğitim öğretmen adaylarının üstbiliş farkındalıklarının tespiti. Ankara Üniversitesi Eğitim Bilimleri Fakültesi Özel Eğitim Dergisi, 17 (03) , 231-245. DOI: 10.21565/ozelegitimdergisi.267315.

Balc1, G. (2007). İlköğretim 5. sınıf öğrencilerinin sözel matematik problemlerini çözme düzeylerine göre bilişsel farkındalık becerilerinin incelenmesi [The examination of metacognitive skills of fifth grade students in terms of their levels of solving verbal math problems]. (Unpublished master's thesis). Çukurova University.

Baloğlu, M. (2003). Individual differences in statistics anxiety among college students. Personality and Individual Differences, 34(5), 855-865. https://psycnet.apa.org/doi/10.1016/S0191-8869(02)00076-4.

Baloğlu, M., \& Zelhart, P. (2004). Üniversite öğrencileri arasında yüksek ve düşük istatistik kaygısının ayrıştırıcıları. Eğitim ve Bilim, 29(133).

Beurze, S. M., Donders, A. R. T., Zielhuis, G. A., de Vegt, F., \& Verbeek, A. L. (2013). Statistics anxiety: a barrier for education in research methodology for medical 
$\begin{array}{lllll}\text { students?. } & \text { Medical } & \text { Science } & \text { Educator, } & \text { 23(3), }\end{array}$

https://doi.org/10.1007/BF03341649.

Bağçeci, B., Döş, B., \& Sarıca, R. (2011). İlköğretim öğrencilerinin üstbilişsel farkındalık düzeyleri ile akademik başarısı arasındaki ilişkinin incelenmesi [An analysis of metacognitive awareness levels and academic achievement of primary school students]. Mustafa Kemal University Journal of Social Sciences Institute, 8(16), 551-566.

Bayar, V., Bayar, A., Eğmir, E., Ödemiş, İ. S., Kayır, G. (2013). Lisansüstü Eğitim Alan Öğrencilerin Bilimsel Araştırma Yapmaya Yönelik Kaygı Düzeyleri. VI. Ulusal Lisansüstü Eğitim Sempozyumu Bildiriler Kitabı. Sakarya Üniversitesi Eğitim Bilimleri Enstitüsü Yayını, No: 6.

Ben-Zvi, D. ve Garfield, J. (2008). Introducing the emerging discipline of statistics education. School Science and Mathematics, 108(8), 355-361. https://doi.org/10.1111/j.1949-8594.2008.tb17850.x.

Benson, J. (1989). Structural components of statistical test anxiety in adults: An exploratory model. The Journal of Experimental Education, 57(3), 247-261.

Blalock, H. M. (1987). Some general goals in teaching statistics. Teaching Sociology, 164172.

Büyüköztürk, S. (1997). Araştırmaya yönelik kaygı ölçeği geliştirilmesi [A scale development of anxiety towards research]. Eğitim Yönetimi Dergisi, 3, 453-464.

Çikrıkci, Ö., \& Odacı, H. (2013). Fen lisesi öğrencilerinin bilişötesi farkındalıkları ile öz yeterlik algılarının bazı kişisel ve akademik değişkenlere göre incelenmesi[Investigating science high school students' metacognitive awareness and self-efficacy perceptions with respect to the some individual and academic variables]. Journal of Human Sciences, 10(2), 246-259.

Cohen, J. (1988). Statistical Power Analysis for the Behavioral Sciences (2nd ed.). Hillsdale, NJ: Lawrence Erlbaum Associates, Publishers.

Collins, K. M. T., \& Onwuegbuzie, A. T. (2007). I cannot read my statistics textbook: The relationship between reading ability and statistics anxiety. The Journal of Negro Education, 76(2), 118-129. Retrieved from http://www.jstor.org/stable/40034551.

Cooper, F. (2008). An examination of the impact of multiple intelligences and metacognition on the achievement of mathematics students. (Unpublished doctoral dissertation). Capella University.

Creswell, J. W. (2003). A framework for design. Research design: Qualitative, quantitative, and mixed methods approaches, 9-11.

Erkuş, A. (2011). Davranış bilimleri için bilimsel araştırma süreci. Ankara: Seçkin.

Everson, H. T., Smodlaka, I., \& Tobias, S. (1994). Exploring the relationship of test anxiety and metacognition on reading test performance: A cognitive analysis. Anxiety, Stress and Coping, 7(1), 85-96. https://doi.org/10.1080/10615809408248395.

Faber, G., Drexler, H., Stappert, A., \& Eichhorn, J. (2018). Education science students' statistics anxiety: Developing and analyzing a scale for measuring their worry, 
avoidance, and emotionality cognitions. International Journal of Educational Psychology, 7(3), 248-285. doi: 10.17583/ijep.2018.3340

Fırat- Durdukoca, Ş. \& Arıbaş, S. (2019). Öğretmen adaylarina yönelik “üstbilişsel farkindalik ölçeği"nin geliştirilmesi . Elektronik Sosyal Bilimler Dergisi, 18 (72), 1541-1557. DOI: 10.17755/esosder.474601.

Flavell, J. (1979). Metacognition and cognitive monitoring: A new area of cognitivedevelopmental inquiry. American Psychologist, 34(10), 906-911. https://psycnet.apa.org/doi/10.1037/0003-066X.34.10.906.

Gargabi, Z. H., Nouri, R., Moradi, A., Sarami, G., \& Karaj, I. (2014). Evaluation of Coping Styles, Metacognition and Their Relationship with Test Anxiety. Journal of Mazandaran University of Medical Sciences (JMUMS), 23. Retrieved from http://jmums.mazums.ac.ir/files/site1/user files 0d0bf0/mousavi-A-10-29-161fcb616b.pdf.

Gelen, İ. (6-9 Temmuz 2004). Bilişsel farkındalık stratejilerinin türkçe dersine ilişkin tutum, okuduğunu anlama ve kalıcılı̆̆a etkisi. XIII. Ulusal Eğitim Bilimleri Kurultayı, İnönü Üniversitesi, Eğitim Fakültesi, Malatya.

Georghiades, P. (2004). Making pupils' conceptions of electricity more durable by means of situated metacognition. Research report. International Journal of Science Education, 26, 85-99.

Gökbulut, Y., Akdağ, M. (2016). Sınıf öğretmeni adaylarının üstbilişsel farkındalık ve matematik kaygı düzeyleri arasındaki ilişkisi [The relatıonshıp between preservice elementary teachers' math anxiety levels and their metacognitive awareness]. International Periodical for the Languages, Literature and History of Turkish or Turkic, 11(9), 461-474. https://www.researchgate.net/deref/http $\% 3 \mathrm{~A} \% 2 \mathrm{~F} \% 2 \mathrm{Fdx}$.doi.org $\% 2 \mathrm{~F} 10.7827 \% 2 \mathrm{Ft}$ urkishStudies.

Guidelines for Assessment and Instruction in Statistics Education Report. (2005). A pre K-12 curriculum framework. American Statistical Association. Guidelines for Assessment and Instruction in Statistics Education Report. (2006). College report of the guidelines for assessment and instruction in statistics education project.

Gül, Ş., Özay-köse, E. \& Sadi Yılmaz, S. (2015). Biyoloji öğretmeni adaylarinin üstbiliş farkindaliklarinin farkli değişkenler açisindan incelenmesi [Compared to different variables of prospective biology teachers' metacognitive awareness]. HAYEF Journal of Education, 12 (1), 83-91. Retrieved from https://dergipark.org.tr/tr/pub/iuhayefd/issue/8802/110015

Güler, N., Teker, G. T., \& İlhan, M. (2019). Lisansüstü Eğitim Öğrencilerine Yönelik İstatistik Kaygısı Ölçeği'nin Türkçeye Uyarlanması. Journal of Measurement and Evaluation in Education and Psychology, 10(4), 435-450. doi: 10.21031/epod.550765.

Gürefe, N. (2015). İlköğretim öğrencilerinin üstbilişsel farkındalıklarının bazı değişkenlere göre incelenmesi [An analysıs of metacognitıve awareness of 
secondary school students in terms of mathematics success and various variables]. International Journal of Education Sciences, 2(5), 237-246.

Irak, M. (2012). Üstbiliş ölçeği çocuk ve ergen formunun türkçe standardizasyonu, kayg1 ve obsesif-kompülsif belirtilerle ilişkisi [Standardization of Turkish form of metacognition questionnaire for children and adolescents: the relationships with anxiety and obsessive-compulsive symptoms]. Turkish Journal of Psychiatry, 23(1), 47- 54. doi: 10.5080/u6604.

Irak, M., Çapan, D., \& Soylu, C. (2015). Üstbilişsel süreçlerde yaşa bağlı değişiklikler. Turk Psikoloji Dergisi, 30(75).

Karagül, S. \& Aslan, C. (2016). Türkçe eğitimi programında lisansüstü öğrenim gören öğrencilerin bilimsel araştırma yapmaya yönelik kaygı düzeyleri [Anxiety levels of graduate students in Turkish language education programme about carrying out scientific research]. Mehmet Akif Ersoy University Journal of Education Faculty, 1 (38), 201-217. Retrieved from https://dergipark.org.tr/tr/pub/maeuefd/issue/24653/260762

Koparan, T. \& Güven, B. (2014). Determination of the Statistical Literacy Levels towards Sampling of 8th Grade Students. Elementary Education Online, 13(4), 1171-1184.

Kurtuluş, A. \& Öztürk, B. (2017). ortaokul öğrencilerinin üstbilişsel farkındalık düzeyi ile matematik öz yeterlik algısının matematik başarısına etkisi [The analysis of the effect of metacognitive awareness and mathematics self-efficacy perceptions on mathematics achievement of middle school students]. Dicle Üniversitesi Ziya Gökalp Eğitim Fakültesi Dergisi, (31), 762-778. DOI: 10.14582/DUZGEF.1840

Küçük-Özcan, Z. Ç. (2000). Teaching metacognitive strategies to 6th grade students. (Unpublished master's thesis). Bogaziçi University.

Landine, J. \& Stewart, J. (1998). Relationship between metacognition, motivation, locus of control, self-efficacy, and academic achievement. Canadian Journal of Counselling, 32(3), 200-212.

Lei, S.A. (2008). Factors Changing Attitudes of Graduate School Students toward an Introductory Research Methodology Course. Education, 128(4), 667-685. Retrieved September 13, 2021 from https://www.learntechlib.org/p/102049/.

Manning, B. H., \& Payne, B. D. (1996). Self-talk for teachers and students: Metacognitive strategies for personal and classroom use. Allyn \& Bacon.

Memiş, A., \& Arıcan, H. (2013). Beşinci sınıf öğrencilerinin matematiksel üstbiliş düzeylerinin cinsiyet ve başarı değişkenleri açısından incelenmesi. Karaelmas Journal of Educational Sciences, 1(1).

Memnun, D. S. ve Akkaya, R. (2009). The levels of metacognitive awareness of primary teacher trainees. Procedia Social and Behavioral Sciences, 1, 1919-1923.

National Council of Teachers of Mathematics (2000). Principles and standards for school mathematics NCTM, Reston, VA.

Onwuegbuzie, A. J., \& Wilson, V. A. (2003). Statistics anxiety: Nature, etiology, antecedents, effects, and treatments-a comprehensive review of the literature. Teaching in Higher Education, 8(2), 195-209. doi: 10.1080/1356251032000052447. 
Onwuegbuzie, A. J. (1997a) Writing a research proposal: the role of library anxiety, statistics anxiety, and composition anxiety, Library \& Information Science Research, 19(1), 5-33. doi: 10.1016/S0740-8188(97)90003-7.

Onwuegbuzie, A. J., Slate, J. R., Paterson, F. R. A., Watson, M. H., \& Schwartz, R. A. (2000). Factors associated with achievement in educational research courses. Research in the Schools, 7(1), 53-65. Retrieved from https://eric.ed.gov/?id=EJ644255.

Onwuegbuzie, A. J., Da Ros, D., \& Ryan, J. (1997). The components of statistics anxiety: A phenomenological study. Focus on Learning Problems in Mathematics, 19(4), 11-35. Retrieved from https://eric.ed.gov/?id=EJ558838.

Onwuegbuzie, A. J., \& Seaman, M. A. (1995). The effect of time constraints and statistics test anxiety on test performance in a statistics course. The Journal of Experimental Education, 63(2), 115-124. doi: 10.1080/00220973.1995.9943816.

Onwuegbuzie, A. J. (2004) Academic procrastination and statistics anxiety, Assessment \& Evaluation in Higher Education, 29(1), 3-19. doi: 10.1080/0260293042000160384.

Öztürk, S., \& Serin, M. K. (2020). Sınıf öğretmeni adaylarının üstbilişsel farkındalıkları ile matematik öğretmeye yönelik kayglarının incelenmesi [examination of preservice primary school teachers' metacognitive awareness with anxiety towards mathematics teaching]. Kastamonu Education Journal, 28(2), 1013-1025. doi:10.24106/kefdergi.705074.

Özsoy, G., Çakıroğlu, A. ve Kuruyer, G. H. (2010). Sınıf öğretmeni adaylarının üstbilişsel farkındalık düzeylerinin bazı değişkenler bakımından incelenmesi. 9. Sınıf Öğretmenliği Eğitimi Sempozyumu, 489-492.

Primi, C., \& Chiesi, F. (2018). The role of mathematics anxiety and statistics anxiety in learning statistics. Paper presented at the 10th International Conference on Teaching Statistics, Kyoto, Japan. Retrieved from https://iaseweb.org/icots/10/proceedings/pdfs/ICOTS10 5E2.pdf.

Roberts, D. M., \& Bilderbeck, E. W. (1980). Reliability and validity of statistics attitude survey. Educational and Psychological Measurement, 40(1), 235-238. Doi: 10.1177/001316448004000138.

Roberts, D. M., \& Saxe, J. E. (1982) Validity of a statistics attitude survey: A follow up study. Educational and Psychological Measurement, 42(3), 907-912. Doi: $10.1177 / 001316448204200326$

Rodarte-Luna, B., \& Sherry, A. (2008). Sex differences in the relation between statistics anxiety and cognitive/learning strategies. Contemporary Educational Psychology, 33(2), 327-344. Doi: 10.1016/j.cedpsych.2007.03.002.

Saracaloğlu, A. S., Varol, S. R., Evin-Ercan, İ. (2005). Lisansüstü Eğitim Öğrencilerinin Bilimsel Araştırma Kaygıları, Araştırma ve İstatistiğe Yönelik Tutumları ile Araştırma Yeterlikleri Arasındaki İlişki. Buca Faculty of Education Journal, 17, 187-199. Retrieved from https://dergipark.org.tr/tr/pub/deubefd/issue/25433/268360.

Saracaloğlu, A. S. İ. (2008). Lisansüstü öğrencilerin akademik güdülenme düzeyleri, araştırma kaygıları ve tutumları ile araştırma yeterlikleri arasındaki ilişki [The 
relationship between post graduate students' academic motivation level, research anxiety and attitudes with their research competence]. Yüzüncü Yil Üniversitesi Eğitim Fakültesi Dergisi, 5(2), 179-208. Retrieved from https://dergipark.org.tr/tr/pub/yyuefd/issue/13714/166039.

Sarıçam, H. \& Kacar, M. (2015). Sınıf öğretmen adaylarının üstbiliş farkındalıkları ile matematik kaygı düzeyleri üzerine bir çalışma [The examination of the relationship between metacognitive awareness and math anxiety levels in preservice primary school teachers] . Trakya Üniversitesi Eğitim Fakültesi Dergisi, 5 (2). Retrieved from https://dergipark.org.tr/tr/pub/trkefd/issue/21482/230229.

Savaşan, İ. (2019). Öğrencilerin sınav kaygısı ile olumsuz üst biliş düzeyleri arasındaki ilişkinin incelenmesi [The relationship between negative metacognition level and test anxiety]. (Unpublished master's thesis). Çağ University.

Schield, M, (2008). Statistical Literacy Skills Survey: Project Kaleidoscope and Project Quirk. 26 Aralık 2011 tarihinde http://www.statlit.org/pdf/2008SchieldPKAL.pdf

Schneider, W., \& Artelt, C. (2010). Metacognition and mathematics education. ZDM Mathematics Education, 42(2), 149-161.

Schunk, D. H. (1989). Social cognitive theory and self-regulated learning. In Selfregulated learning and academic achievement (pp. 83-110). Springer, New York, NY.

Senemoglu, N. (2015). Gelisim, ögrenme ve ögretim: Kuramdan uygulamaya. [Development, learning and teaching: From theory to practice]. Ankara: Yarg1 Yayınları.

Spada, M. M., Georgiou, G. A., \& Wells, A. (2010). The relationship among metacognitions, attentional control, and state anxiety. Cognitive Behaviour Therapy, 39(1), 64-71. DOI: 10.1080/16506070902991791.

Sutarso, T. (1992). Some variables in relation to students' anxiety in learning statistics. Paper presented at the Annual Meeting of the Mid-South Educational Research Association, Knoxville, TN (ERIC document number ED-353334). Retrieved from https://files.eric.ed.gov/fulltext/ED353334.pdf

Tan, Ş. (2016). SPSS ve Excel uygulamalı temel istatistik-I. Ankara: Pegem Akademi.

Tekin, H. (1996). Eğitimde Ölçme ve Değerlendirme. Ankara: Yarg1 Yayınları

Tuncer, T. (2011). Matematik dersi yedinci sınıf "permütasyon ve olasılık" konusunda uygulanan üstbiliş stratejilerinin, öğrencilerin başarılarına, üstbiliş becerilerine, tutumlarına ve kalıcılığa etkisi. (Unpublished master's thesis). Atatürk University.

Wells, A., \& Matthews, G. (1996). Modelling cognition in emotional disorder: The S-REF model. Behaviour Research and Therapy, 34(11-12), 881-888. Retrieved from https://www.sciencedirect.com/science/article/abs/pii/S0005796796000502

Wilson, V. (1997). Factors related to anxiety in the graduate statistics classroom. Paper presented at the annual meeting of the Mid-South Educational Research

Association, Memphis, TN (ERIC document number ED415288). Retrieved from https://files.eric.ed.gov/fulltext/ED415288.pdf. 
Yılmaz, K. ve Çokluk, Ö. (2010). Fen - Edebiyat Fakültesi mezunlarının araştırma kaygı düzeyleri [Research anxiety levels of faculty of arts and science graduates]. Abant İzzet Baysal Üniversitesi Dergisi, 10(1), 1-9.

Zeidner, M. (1991). Statistics and mathematics anxiety in social science students: Some interesting parallels. British Journal of Educational Psychology, 61(3), 319- 328. DOI: 10.1111/j.2044- 8279.1991.tb00989.x. 

to copy, distribute, transmit or adapt the article content, providing a proper, prominent and unambiguous attribution to the authors in a manner that makes clear that the materials are being reused under permission of a Creative Commons License. Views, opinions and conclusions expressed in this research article are views, opinions and conclusions of the author(s). Open Access Publishing Group and European Journal of Education Studies shall not be responsible or answerable for any loss, damage or liability caused in relation to/arising out of conflicts of interest, copyright violations and inappropriate or inaccurate use of any kind content related or integrated into the research work. All the published works are meeting the Open Access Publishing requirements and can be freely accessed, shared, modified, distributed and used in educational, commercial and non-commercial purposes under a Creative Commons Attribution 4.0 International License (CC BY 4.0). 